\title{
Government expression and the Covid-19 pandemic: advising, nudging, urging, commanding
}

\author{
Dean R Knight*
}

(2020) 31 Public Law Review 391

\section{Introduction}

Expression has been at the forefront of the New Zealand government's response to the Covid-19 pandemic. Stopping the spread of the virus has required fundamental behaviour change among the citizenry. Sociological change was encouraged, invited and demanded through advice, nudges, urges and commands. And, by-and-large, it worked: people's dayto-day behaviour changed - fundamentally - in order to help eliminate the virus. But this chorus of expression was not always harmonious; sometimes the messages were a bit messy or discordant, especially in the early days of the nationwide lockdown.

Efficacy aside, though, what does the rule of law make of this chorus of expression by the government? One answer to that question came from a full bench of the High Court in Borrowdale v Director-General of General Health, which found that some of the government expression in the first week or so of lockdown failed the rule of law. ${ }^{1}$ When people were told, among other things, to stay at home, this expression lacked the necessary legal mandate, until an additional formal health order was issued nine days in. The Court ruled those messages amounted to "restrictive measures" that effectively limited citizen's mobility rights; such expression was unlawful because it was not prescribed by law. ${ }^{2}$ Underlying this analysis is a sharp and precise conception of the rule of law. The rule of law cherishes a special and rarified type of state expression: law. Law speaks, and speaks with special force. At its most basic, law frames obligations and generates consequences if not obeyed. And, in our democratic system, it is that law that is expected to rule and to rule supremely over other expression. But is that the only view of the demands of the rule of law?

In this note I reflect on the role of expression during the pandemic and the rule of law issues generated in the early days of lockdown. In doing so, I take issue with the conception of the rule of law that underpinned the Court's conclusion that some early messaging was unlawful. Another account of the rule of law might have been able to provide constitutional comfort about the impugned government expression in those early days.

\footnotetext{
Associate Professor, Faculty of Law and New Zealand Centre for Public Law; Victoria University of Wellington (dean.knight@,vuw.ac.nz).

1 Borrowdale v Director-General of Health [2020] NZHC 2090.

2 Borrowdale, above n 1, at [240].
} 


\section{Expression and the pandemic}

The response to the Covid-19 pandemic saw a chorus of expression - a massive and multifaceted wave of communications designed to change behaviour to slow and stop transmission of the virus. And the communications strategy was not just about the nationwide lockdown in March and April 2020. The response to the virus kicked off much earlier, even though the first case was not diagnosed until the end of February. ${ }^{3}$

The chorus began in late-January 2020 when Covid-19 was declared a notifiable infectious disease. ${ }^{4}$ Travel warnings, discouraging travel to China and elsewhere, were issued. ${ }^{5}$ Passengers on a repatriation flight from Wuhan province in China were ordered to quarantine at a naval base. ${ }^{6}$ Instructions were issued closing the border to travellers, other than to citizens and residents, in mid-March. ${ }^{7}$ Returning residents were directed to self-isolate. ${ }^{8}$ Large-scale events were advised not to proceed. ${ }^{9}$ People were told to adopt hygiene measures to minimise the risk of transmission: "wash your hands"; "cough into your elbow"; and even abandon handshakes and hongi in favour of the "East coast wave" (raising of eyebrows while slightly raising one's head). ${ }^{10}$ The director-general of health, Dr Ashley Bloomfield, started giving daily media briefings on the pandemic, detailing the number of cases and circumstances of transmission.

Late March saw the expression amplify. On Saturday 21 March 2020, the prime minister, Jacinda Ardern, made a rare live address to the nation from her Beehive office. she announced an alert level framework - a non-statutory guide about pandemic conditions and expected restrictions. ${ }^{11}$ The country was placed at level 2 and warned to prepare for disruption. ${ }^{12}$ At risk people such as the elderly were asked to stay at home. People were asked to work from home or to adopt other mitigation arrangements. And everyone was asked to limit their movements around the country.

On the following Monday, came another public address from the prime minister. The alert level was immediately elevated to level 3 and the prime minister signalled it would be further elevated to level 4 - a nationwide lockdown - from midnight on Wednesday, 25 March 2020.13 "[W] are now asking all New Zealanders who are outside essential

3 Ministry of Health "Single case of COVID-19 confirmed in New Zealand" (28 February 2020)

$<$ www.health.govt.nz>.

4 Infectious and Notifiable Diseases Order 2020 (28 January 2020).

5 "Wuhan virus: What should air passengers and travellers know?" (NZ Herald, 24 January 2020)

$<$ www.nzherald.co.nz>.

6 "Coronavirus: Evacuating NZers from Wuhan - what you need to know" (3 February 2020) RNZ

$<$ www.rnz.co.nz>.

7 Cabinet Minute "Novel Coronavirus: Update and Enhanced Border Measures" (2 February 2020) CAB15.

8 Ashley Bloomfield, "Section 70(1)(f) notice to arrivals" (16 March 2020) <www.covid19.govt.nz>.

9 Cabinet Minute, “COVID-19: Mass Gatherings” (16 March 2020) CAB-20-MIN-0111.

10 Eleanor Ainge Roy "East coast wave' should replace handshakes and hongi amid coronavirus, says Jacinda Ardern" (17 March 2020) The Guardian <www.theguardian.com>.

11 New Zealand Government “Alert System Overview” (23 September 2020) <www.covid19.govt.nz>.

12 Jacinda Ardern "PM Address - Covid-19 Update" (21 March 2020) <www.beehive.govt.nz>.

13 Jacinda Ardern "Covid-19 Alert Level Increase” (transcript, 23 March 2020) <www.beehive.govt.nz>. 
services", the prime minister said, "to stay at home, and to stop all interactions with others outside of those in your household". ${ }^{14}$ A state of national emergency was declared under the Civil Defence Emergency Management Act 2002 (NZ) and an outbreak of the virus was declared under the Epidemic Preparedness Act 2006 (NZ), thereby unlocking various special emergency powers. ${ }^{15}$ And on the eve of the lockdown, a national emergency management agency alert was sent to all mobile phones in the country, advising people to "follow the rules and stay at home". ${ }^{16}$

Formal orders were also made. A health order was issued by the director-general under the Health Act 1956 (NZ), directing premises other than essential businesses to close and to prohibit congregation in public places without physical distancing. ${ }^{17}$ More orders followed. A more extensive health order was issued on 3 April, requiring all people to isolate in their households, except as permitted for prescribed permissible movement. ${ }^{18}$ Orders were later tweaked and substituted as the alert levels were lowered.

Daily briefings continued throughout the lockdown. The prime minister, the directorgeneral of health and others addressed assembled media in the Beehive briefing room, with proceedings also broadcast widely on most media channels and on the internet. Messages to stay at home, be kind and shop sensibly, among other things, were relayed. Soundbites advising of risks, counselling precautions and highlighting key rules were peppered on television and radio, and plastered on billboards and in public spaces.

This is only a small sample of the expression through the pandemic. It is impossible to recount and parse all this expression. But it is fair to say that it involved the full range of expressive activity - from advising to nudging to urging to commanding. By that I mean a continuum of compulsion and formality in a descriptive sense. I do not promote this language as a rigid taxonomy with acute legal significance; rather, it is merely a way to capture the diversity of expressive activity.

\section{Rule of law challenge to early lockdown expression}

Against that backdrop, enter Borrowdale. One part of the judicial review proceedings tested expression against rule of law standards. ${ }^{19}$ Borrowdale argued that urging people to stay at home during the first week or so of the lockdown lacked any legal mandate. It followed,

14 Jacinda Ardern "Covid-19 Alert Level Increase” (transcript, 23 March 2020) <www.beehive.govt.nz>.

15 Jacinda Ardern, “Epidemic Preparedness (COVID-19) Notice 2020” (24 March 2020) <www.gazette.govt.nz>; Peeni Henare, "Declaration of State of National Emergency by Minister of Civil Defence" (25 March 2020) <www.gazette.govt.nz>.

16 Borrowdale, at [162].

17 Ashley Bloomfield, "Section 70(1)(m) notice to close premises and forbidding congregation in outdoor places of amusement or recreation" (25 March 2020) <www.covid19.govt.nz>. Oddly, although executed on the same day the alert level rose to level 4, this order was not publicly mentioned or released until a couple of days later: see Ashley Bloomfield and others, "All of Government Press Conference" (transcript, 27 March 2020) <www.beehive.govt.nz>.

18 Ashley Bloomfield, "Section 70(1)(f) notice to all persons in New Zealand" (3 April 2020) $<$ www.covid19.govt.nz>.

19 Borrowdale, above n 1, at [140] 
he said, that those "directions": (1) suspended laws without parliamentary consent contrary to s 1 of the Bill of Rights 1688 (UK) (English Bill of Rights); and/or (2) unlawfully limited rights in the New Zealand Bill of Rights Act 1990 (NZ) (NZ Bill of Rights Act) because any limitation was not prescribed by law. The Court rejected the first proposition but accepted the second.

The English Bill of Rights allegation can be dealt with quickly. The Court did not consider the statements purported to render laws (in this case, the protective provisions in the NZ Bill of Rights $A c t)$ inoperative. Even if the statements had similar intention to legislative decrees, they did not amount to the suspension of law - and the old law was only concerned with suspension, not promulgation. The lockdown messages were not in the same class as a prime ministerial pronouncement that a legislatively enshrined superannuation scheme would cease operating immediately, as was famously ruled unlawful in Fitzgerald $v$ Muldoon. ${ }^{20}$ Although the Court did not elaborate much on the inapt analogy, there is an obvious difference between directive expression that cuts across a classically autonomous law and a legal regime like the NZ Bill of Rights Act that expressly contemplates dynamic interaction with other laws and executive action. Indeed, the $N Z$ Bill of Rights Act provides an internal calculus - namely s 5 - for determining the priority and balance between protective rights and action by the executive. In any event, the Court also thought the analogy was inapt because the director-general could have lawfully limited those rights, in accordance with Parliament's mandate and delegation in the Health Act, by issuing a health order requiring isolation, as he did after nine days; the separation of powers and parliamentary supremacy concerns underpinning Fitzgerald $v$ Muldoon did not arise.

On the second allegation, the Court ultimately ruled that urging people to stay at home was not prescribed by law as required by the NZ Bill of Rights Act and unlawfully limited people's mobility rights. ${ }^{21}$ First, the Court concluded the statements "conveyed that there was a legal obligation on New Zealanders to comply: to stay home and remain in their bubble".22 While government expression included some soft messaging asking people to change behaviour and counselling things like kindness, the public statements were also "replete with commands": 23 the language of "must", "rules" and "enforcement" was dotted throughout the statements. ${ }^{24}$ Also, statements from the prime minister "carried with them the full authority of her office and the State", adding to their normative force. ${ }^{25}$ "The overwhelming impression was that compliance was required by law", the Court said, "indeed, that is how we interpreted them at the time". ${ }^{26}$ Secondly, given the obligatory

20 Fitzgerald v Muldoon [1976] 2 NZLR 615 (SC). See generally Stephen Kos, "Constitutional collision: Fitzgerald v Muldoon v Wild” (2014) 13 Otago LR 243.

21 Borrowdale, above n 1, at [175] and [176].

22 Borrowdale, above $\mathrm{n} 1$, at [191].

23 Borrowdale, above $\mathrm{n}$ 1, at [184].

24 Borrowdale, above $\mathrm{n}$ 1, at [184].

25 Borrowdale, above n 1, at [187].

26 Borrowdale, above $\mathrm{n} 1$, at [190]. 
character of the statements, the statements limited certain mobility rights protected in the NZ Bill of Rights Act. Remaining at home in household bubbles inexorably limited freedoms of movement (s 18) and association (s 17). Thirdly, there was no legal obligation backing up the statements, especially as there was no rule requiring people to isolate at home (until the second health order was promulgated on 3 April 2020). ${ }^{27}$ The absence of authorisation meant the limitation of rights was not prescribed by law and therefore contrary to the NZ Bill of Rights Act, as the Court declared by way of relief. ${ }^{28}$

Importantly, any knock-on consequences did not need to be addressed by the Court because the proceedings did not seek to directly impugn any enforcement actions based on those messages. Indeed, the police's light-handed approach in the early days of lockdown - to "educate and encourage" in the first instance - probably means few, if any, consequential actions were legally implicated by the declaration. Only 25 people were prosecuted in the early days of lockdown and only a couple of hundred warnings issued. ${ }^{29}$ However, it was never clear whether those charges and warnings related to noncompliance with then applicable health orders, individualised directions or the impugned message to stay at home. The case only looked at the broadcast side of expression evidence about the reception and consequences was sparse.

\section{Analysis}

The successful argument in Borrowdale was quintessentially a basic rule of law argument about legal mandate, even though coloured by the language of the NZ Bill of Rights Act and framed by its "prescribed by law" requirement. The core allegation was that the prime minister and other officials did not have the legal power to engage in that type of expression in those circumstances. This question could also have been framed in traditional administrative law terms: whether the government had legal authority to urge or command people to stay at home, under statute, prerogative or otherwise (such as by dint of any residual freedom or third source of authority). ${ }^{30}$

Central to the Court's reasoning and conclusion of unlawfulness was a particular view of the rule of law - and, indeed, its component parts: the concept of law; and the concept of ruling. Law is equated with command, in an almost Austinian way. ${ }^{31}$ In other words, law is a specific rule that has been publicly promulgated, the breach of which is enforceable through coercive sanctions. And it is those commands that must rule and rule directly. A command - a stated obligation and threat of coercion - is the proper way for state actors to induce behavioural change. Armed with this conception of the rule of law,

27 Borrowdale, above $\mathrm{n} 1$, at [225].

28 Borrowdale, above $\mathrm{n} 1$, at [292].

29 Borrowdale, above $\mathrm{n} 1$, at fn 94.

30 Bruce Harris “The 'Third Source' of Authority for Government Action Revisited” (2007) 123 LQR 225; “Government 'Third-Source' Action and Common Law Constitutionalism (2010) 126 LQR 373; "Recent Judicial Recognition of the Third Source of Authority for Government Action" (2014) 26 NZULR 60. It is generally accepted that the residual freedom or third source cannot operate to limit rights but the definition of the latter (common law or statutorily enshrined; fully expressed rights or subject to reasonable limits) needs attention.

31 John Austin, The Province of Jurisprudence Determined (1832, John Murray, London). 
there is no doubt that the search for any law corresponding with the government's urgings to stay at home came up empty. While commands were issued, they were deployed to change other types of behaviour: closure of premises and stopping public congregation. There was no lawful command to stay at home.

But, in the absence of a lawful command to stay at home, could the putative gap between government expression and legal mandate be filled by other legal tools? The Court looked at this possibility briefly, in the context of a backup argument from government but quickly dismissed it - in my view, too quickly.

If the message to stay at home was seen, not as a command in and of itself, but signalling the intended effect of a network of emergency regulatory powers and tools, then the claimed gap between expression and law largely evaporates. The rule of law requirement of prior authorisation is satisfied by the triggering of the emergency settings and the temporary legal regime it ushers in - made up of a network of directive and other powers that could be used to combat the pandemic. Medical officers of health have longstanding special powers under s 70 of the Health Act - including the power to require people to isolate or quarantine - in order to combat infectious diseases during a state of emergency, declared epidemic or when otherwise authorised. ${ }^{32}$ Failure to comply with a direction is an arrestable and imprisonable offence. ${ }^{33}$ The main argument in the Borrowdale case was whether this power could be used by the director-general of health to require the entire nation to isolate, with the Court ruling it could be used on this universal basis. ${ }^{34}$ But the pedigree of the power is traditionally devolved and individualised: a power to be used on-the-ground by key medical officials in their communities; its use on the national stage was an exception, not the rule. And, with emergency settings triggered, directions were given on a case-by-case basis, both during the lockdown and in the precursor period. Civil defence controllers and constables also have directive powers under s 91(1)(a) of the Civil Defence Emergency Management Act during states of emergency, allowing them to "direct any person to stop any activity that may cause or substantially contribute to an emergency". This power could be engaged to direct people not staying in their household bubbles when the latter causation or contribution threshold is met. Civil defence legislation also allowed the closure of roads - a power used in a number of instances in order to limit emergency risks. ${ }^{35}$ Closure of all roads, subject to authorised travel, could have been an indirect way to keep people confined to their homes.

The Court, however, doubted the potency of these tools and any suggestion they were capable of backing up the message to stay at home. First, it doubted the practicality of

32 Since the beginning of the last century, these special powers have been available to medical officer of health when authorised by ministers; ad hoc authorisation has been blended with automatic authorisation when emergencies and epidemics are declared: see Borrowdale, above n 1, at [66]-[70].

33 Health Act 1956, s 72(d).

34 Borrowdale, above n 1, at [135]; MB Rodriguez Ferrere, "Borrowdale v Director-General of Health: An Unlawful But Justified National Lockdown” (2020) 31 PLR 1.

35 Civil Defence Emergency Management Act 2002, s 88. 
engaging s 70, saying the prospect of it being engaged when two household bubbles intermingled "seems remote". ${ }^{36}$ But that is precisely how the emergency powers were expected to be, and were, used. Secondly, the Court said it was "unlikely" that a failure to stay at home would meet the threshold for exercise of the s 91 power. In this context, the threshold question is crucial. Admittedly, the threshold reads a bit clumsy in the case of a pandemic but there is a plausible reading that comingling outside a household bubble could contribute to the emergency (ie a situation such as an epidemic if it "causes or may cause loss of life or injury or illness or distress or in any way endangers the safety of the public")..${ }^{37}$ It is not hard to foresee how comingling might cause the virus to quickly spread exponentially, thereby creating a situation that endangers the safety of the public. And, again, evidence testifies to this power being used on the ground in, for example, directing freedom campers to relocate and closing facilities like dog recreation areas. ${ }^{38}$ But, disappointingly, the Court did not undertake any serious or deep analysis of the question.

As an aside, there were hints that the threshold for this directive power might have caused some friction within government during the early days of lockdown, perhaps blunting one of the tools the government expected to rely on. Police operational guidelines issued in the first week of lockdown suggested the threshold would only be met in circumstances where a person not isolating at home was a recent returnee or was exhibiting symptoms of the virus. ${ }^{39}$ While not binding on frontline police, who retain their own constabulary discretion, reluctance to employ this tool would have diluted enforcement quite a bit. This might provide an explanation for the subsequent fortification of the lockdown rules. However, crucially, the potency of the civil defence directive power was not tested nor seriously explored by the Court.

These directive powers, when combined with the extant health orders closing premises and forbidding public congregation, would make the government's key urges legally authentic - in other words, the message to stay at home could be legally enforced, albeit through a range of different legal tools. And, looking back at the government's messaging at the time, that is also a fair account of how emergency settings and requirements were explained - even with the government admitting it was still "to sort out the exact details" going into lockdown. ${ }^{40}$ Much of the government explanation of enforcement was nonspecific; the government spoke generally about rules and expectations being enforced but did not particularise the mode of enforcement for different expectations. Some statements about enforcement were no doubt attributable to hard legal rules in play, such as the closure of premises and prohibition of congregation; these commands were

36 Borrowdale, above n 1, at [223].

37 Civil Defence Emergency Management Act 2002, s 4 “emergency”.

38 Sarah Stuart-Black "Sixth Extension of the State of National Emergency for COVID-19" (National Emergency Management Agency, Briefing 20/50, 5 March 2020) <www.dpmc.govt.nz> at Appendix 4.

39 New Zealand Police, "Operational Policing Guidelines - Alert Level 4, Scenarios for the Frontline Police" (March 2020).

40 Ashley Bloomfield, quoted in Borrowdale, above n 1, at 281. 
enforceable directly through powers of arrest and prosecution. Enforcement of other messages was more contingent and relied on escalation. But that was also alluded to. For example, the brief explanations of enforcement referred to different tools and numerous powers, the "ability to escalate", "other enforcement action" and so forth. ${ }^{41}$ Perhaps notable was the tendency to employ the language of enforcement action rather than the more direct and command-like language of arrest and prosecution. A degree of opacity or "normative ambiguity" - about the means of enforcement may not have been accidental. ${ }^{42}$

The Court, though, was troubled by this network of directive powers and was sceptical about whether it gave the message to stay at home the necessary legal underpinning. ${ }^{43}$ Describing this style of enforcement as "[un]satisfactory", the Court worried about the contingent nature of case-by-case enforcement, dependent as it was on prior steps and imposition of additional legal obligations. ${ }^{44}$ Again, this reveals the Court's penchant for a command model of the rule of law and expectations of tight congruence between expression and legal mandate.

More generally, the command-only approach to the rule of law sits uncomfortably with the legal framework for emergencies and pandemics. Remember, emergency settings for the pandemic enlivened an armoury of different, perhaps unusual, legal powers: on-theground officials are given authority to use a range of discretionary and heavily coercive directive powers, as and when necessary. That makes sense. Emergencies require acute responsiveness to deal with circumstances that may be fast-moving, unpredictable and overwhelming. ${ }^{45}$ Declarations of emergencies, whether we like them or not, temporarily usher in adjusted legal orders. Unsurprisingly, legal orders associated with emergencies place greater emphasis on discretionary power than traditional modes of legislative rulemaking. Indeed, the Court's liberal reading of the power to issue health orders, in the context of the other part of Borrowdale's claim, was based on an appreciation of the need for emergency health powers to be nimble and discretionary. ${ }^{46}$

Discretionary directive powers are also not unknown in non-emergency settings. Consider, for example, the power of environmental health officers to issue excessive noise directions. ${ }^{47}$ Further, while some narrow versions of the rule of law are hostile to discretionary power, others recognise their place in the legal order. For example, Raz famously reasoned that "particular laws" or "particular legal orders" did not offend the generality requirement of his "rule book" conception of the rule of law and were acceptable if the exercise of the inherent discretion associated with them was guided by open, stable, clear and general rules. ${ }^{48}$

41 Borrowdale, above $\mathrm{n} 1$, at [148]-[173].

42 Tom Hickman, "The Use and Misuse of Guidance during the UK's Coronavirus Lockdown" ("normative uncertainty") (Working Paper, 15 June 2020) <www.ssrn.com> at 3.

43 Borrowdale, above n 1, at [224].

44 Borrowdale, above $\mathrm{n}$ 1, at [224].

45 Kristian Cedervall Lauta, Disaster Law (Routledge, 2016).

46 Borrowdale, above n 1, at [49]-[70] and [100]-[139].

47 Resource Management Act 1991, s 327.

48 Joseph Raz, "The Rule of Law and Its Virtue” (1977) 93 LQR 195. 
Recognising this network of powers also does not give government unfettered power to demand behaviour change among citizens by edict. First, such a broad network of powers is relatively unusual to the emergency settings so triggered. Acknowledgment of its role in underpinning expressive demands here does not open the door generally to governance by decree. Authentic and fair expression that is reflective of legal underpinnings continues to be required; the nature of the legal underpinning, not any quibble with the need for legal mandate, was the unique dimension in this context. Secondly, for the declaration of an emergency and an enlivened network of powers to authentically fill the gap, there still needs to be some congruence between the message made with normative force and the ability for them to be enforced. Such a requirement stays faithful to the primacy of law and also reflects the rule of law/prescription by law expectation that exercises of discretion be guided and predictable. ${ }^{49}$ Thus, it is tricky to see how the individualised directive powers could justifiably be invoked against a mountain biker or surfer outside their bubble by themselves and messages accordingly would be vulnerable to challenge. However, instances of household bubbles commingling carried a much more tangible risk of fuelling transmission of the virus. Thirdly, the rule of law's interest does not end with legal mandate and authority. Obviously, the exercise of the network of powers - like other exercises of government power - would need to be reasonable and rights-consistent. Unreasonable, unjustified or disproportionate nudging or urging would be unlawful.

I wonder if some of the Court's scepticism may have been fuelled by the curious way the government sought to mandate the urging to stay at home. Rather than seizing forcefully on the emergency declaration and related network of latent legal powers, the government tried to argue that urging people to stay at home was merely public health advice and only voluntary compliance was expected. Or, if the message to stay at home came with normative force, it was an implied exercise of the power of the director-general to universally direct the community at large. The problem with these alternative theories was that neither was particularly authentic. Clearly, as the Court rightly found, the advice to stay at home was not neutral. It came with normative force and an expectation that people would comply. Suggesting otherwise was a rather odd attempt at revisionism. So too the implied directive power - which came across as another cunning attempt to rewrite the history of the early days of the lockdown. And neither of these arguments was necessary in my view. It was not a binary choice between optional advice and mandatory command; shades of expression in between were capable of being legally authorised and justified.

\section{Conclusion}

The Court condemned the lack of legal mandate for the early days of lockdown, inspired by a tempting command view of the rule of law. An alternative view is that the nature of law that ruled through the pandemic was more complex: a chorus of expression, backed up by a multifaceted network of emergency legal powers. The latter view is not disloyal to

49 See for example R $v$ Hansen [2007] NZSC 7, [2007] 3 NZLR 1 (McGrath J), as adopted in Borrowdale, above n 1, at [200]. 
the rule of law; nor does it suggest the rule of law can be dodged during an emergency. Instead, it adopts a view of law that is more commensurate with the mandate given to government agents to rule through the fast-moving vicissitudes of emergencies like pandemics. The prior authorisation - or prescription by law - of people being urged to stay at home came from the legislative delegation to invoke the emergency settings and rely on the legally enforceable directive powers reposed in officials. That is not to abandon the rule of law but to acknowledge the type of law in play during a pandemic and the manner in which it rules. 